HStud 26 (2012)1, 67-78 DOI: 10.1556/HStud.26.2012.1.6

\title{
TO BE BORN INTO EXILE
}

\author{
KELEMEN MIKES AND THE 19-20TH CENTURY \\ HUNGARIAN LITERARY EXILES
}

\begin{abstract}
SÁNDOR HITES
Institute for Literary Studies, Research Centre for the Humanities, Hungarian Academy of Sciences, Budapest, Hungary
\end{abstract}

\begin{abstract}
The paper deals with the roles the literary and political legacy of Kelemen Mikes (1690-1761) and his Letters from Turkey have come to play in Hungarian literary emigration. Unlike Mikes's 19th century cult, which interiorized exilic experience inasmuch as it provided an allegory for domestic political claims, in the 20th century the consecutive exilic waves (1944-45, 1947-48, 1956) increasingly identified Mikes with a peculiar exilic consciousness, which they felt to mirror their own in various ways. Accordingly, the figure of Mikes was designed, mainly in essay and in poetry, to represent and reinforce a wide range of diverse political and literary self-images, from nationalism to apolitical aesthetic modernism, from the experience of the Hungarian writer as a castaway to that of genuine human foreignness.
\end{abstract}

Keywords: Kelemen Mikes, Letters from Turkey, 19th-20th century literary exile, political literature, cultural identity

After the fall of the 1848 revolution many Hungarians sought asylum in exile. The Transylvanian novelist Baron Miklós Jósika fled to Brussels. There he lived until 1864, then moved to Dresden, where he died a year later. In the summer of 1862 , still in Brussels, Jósika and his wife were changing residence, because, due to Jósika's increasing revenue from his literary works, published anonymously in Hungary, they were able to build a house of their own and leave the flat they had been renting for a decade. A letter he wrote on 1 June to his friend Miklós Fejérváry, an émigré himself, living then in Davenport, United States, Jósika starts with a curious remark:

Miként látod, még e levelemet régi sátoromban írtam, hol a török közmondás szerint még egypár kenyerem van letéve. ${ }^{1}$

[As you can see, this letter of mine has been written in my old tent, where, according to the Turkish saying, a few pieces of bread are still deposited for me.] 
Jósika's letters are usually full of sarcastic hints and allusions. He often makes similar jokes, occasionally referring to his flat as a wigwam, the North American version of a tent, which is quite motivated in a letter written to a friend in North America. Nevertheless, the sentence I quoted resembles one of Mikes' most moving image of exilic fate, recurring in several letters (such as Letters 7, 16, 19, 32, 157), that God deposited certain amounts of bread at certain places for each human being, compelling him or her to go and stay there and live upon that bread as long as it lasts. Jósika never mentions Mikes' name in his correspondence, and Mikes does not appear either in his novel on Rákóczi, written in the 1850s, already in exile. ${ }^{2}$ However, the image of the bread in that particular letter seems to echo Mikes in such a straightforward way that it might be reasonable to assume that Jósika - when describing a dilemma so typical of émigrés, whether to move on or stay $^{3}$ - deliberately alludes to the Letters from Turkey. What seems to affirm this conjecture is that Toldy's new edition of Mikes' magnum opus was released in the previous year, $1861,{ }^{4}$ by the publisher Gustav Heckenast who also happened to be the publisher of Jósika's novels since the 1830s. Hence, he might have managed to get a copy directly from the publisher.

Apart from the question whether Jósika deliberately employed the same image as Mikes to depict the existential condition of émigrés, this quote represents a conjunction surprisingly unique in 19th century Hungarian exilic literature. To my knowledge, the literary emigrants or expatriates of the age such as János Batsányi, József Eötvös, or Lajos Degré, never referred to Mikes in their writings.

I would argue that during the 19th century Mikes, in the strict sense, was not a symbol of and not a symbol for the exile. When his cult developed, from the mid-1800s onwards, his legacy was designed to interpret domestic political affairs, like the revolutionary events of 1848 or Kossuth's death at the end of the century. In the poetry of Mihály Vörösmarty, József Lévay or János Arany Mikes' exile came to symbolize the lack of liberty in the homeland, and, in terms the exilic psyche, Mikes' allegiance and devotion served as a reflection of present political conditions. Making loyalty his emblematic feature, Mikes' name became a rhetorical substitution of Prince Ferenc Rákóczi, a figure who on the other hand rhetorically stood for the nation's claim to independence. Even in Lévay's poem, which comes closest to depict an exilic state of mind, Mikes' longing for his native village in Transylvania, Zágon is ultimately a yearning for an ideal homeland identical with liberty. In Mikes' cult exile was a question of being in or out merely in a geographical sense, inasmuch as it did not represent any rupture of personal or collective consciousness. His exilic experience, that is, a displacement of perspective, was not external, but interiorized into the unity of national self-representation.

It is, then, quite a late development in Mikes' cult that he came to represent a specific exilic consciousness, and it did not came immediately even with modern- 
ism. For the 1919 émigrés, mostly politicians of the Commune and left-wing writers, Mikes represented no symbolic value whatsoever. Presumably, they saw a romanticized nationalistic icon in him, to which they did not intend to relate their efforts. Only with the literary and political exiles of the 1940-50s did Mikes' legacy become a reference for emigrant self-identification.

In what follows I'm going to deal with these subsequent waves of 1944-45, $1947-48,1956$ to outline continuities and discontinuities in the ways they approached the notion of exile and the legacy of Mikes. I shall distinguish between two generations of emigrant writers, with different aesthetic and political predilections, to highlight a shift in the way they related themselves to Mikes respectively.

In an article written for Pesti Hírlap in September 1942, Sándor Márai describes his journey to Zágon, Mikes' birthplace, then recently re-annexed to Hungary. The text, figuring the notions of home, solitude, castaway, truth and legend, represents a moment of transition from the 19th century romantic myth to its modern decomposition. The memorial places, the alleged house of Mikes' birth, the oak-trees said to be planted by his father, are of no importance to Márai. Still, he revives the obligatory images from Lévay's poem (the symbolic force of the name "Zágon" that echoes the word "homeland", the "star" above the village that points to an unidentified secret meaning of the nation's unity) and place them in the metaphysical framework of a dubious notion of Volksgeist. What really counts to Márai, however, is what he considers the "gift" that Mikes gave to all subsequent generations of Hungarian writers: the Hungarian literary language itself. For what makes Márai comfortable on his trip is his impression of being the guest of a "dead fellow writer", to whom an intimate commonality relates him. As he puts it:

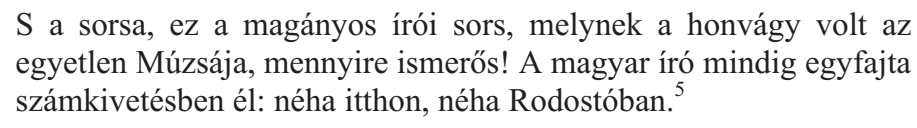

[And his fate, this solitary literary fate, which had only one Muse, homesickness, how familiar! A Hungarian writer always lives as some sort of castaway: sometimes at home, sometimes at Rodostó.]

With this emphatic sign Márai could refer to his own exilic experiences in the 1920 s, but actually says a lot more than that. He refigures the notion of castaway as the general existential condition of a writer's profession, hereby distances himself from the ideology that constitutes the political framework of his argument on the other hand.

This personal intimacy and this refiguring of the notion of exile, however, gets overshadowed by the light of a "star", Lévay's star once again, that reappears in the last passage, and promises to enlighten the way to the secret of a collective 
meaning. This contradiction, the dichotomies between rupture and continuity, intimacy and collectivity, homeland and perpetual exile, pervade the whole structure of the text: mythical national collectivity emblematized by commonplace Mikes-images on the one hand, and the overwhelming feeling of being inherently a castaway as a Hungarian writer on the other.

By that time, Márai was between two emigrations: the 1920s he spent in Germany and France, after 1948 he lived in Italy and the United States. His first exilic period was characterized by the search for a synthesis of European identity and national heritage on the multicultural scenes of post-World War I Paris and Berlin, and the dilemma whether to become a writer in German. His second emigration brought forth his conviction that exile is foremost the alienation of language, which ineluctably threatens to deprive one of his mother tongue, that is, of his personal identity. The image of Mikes as a symbol of the inherently exilic conditions Márai thought a Hungarian writer necessarily lives in represents a transitional stage in this shift of perspectives.

The historical circumstances that provided the occasion for Márai’s article, the re-annexation of the northern part of Transylvania to Hungary, also gave a solid political context to what the very controversial Transylvanian novelist from the political right, Albert Wass, had to say about Mikes. At the end of World War II, when Transylvania was repossessed by Romania, Wass fled to Germany, and later settled in the United States. In the early years of his exile, in 1947, he wrote a piece of poetry with Mikes-allusions, entitled Levél [Letter], addressed to someone he calls "father". The poem enumerates and reaffirms all the worn-out topi of Lévay, "the murmuring of the sea", "the stars pointing to Zágon" etc., and the speaker, who claims to dream the "dreams of a new Rodostó", refers explicitly to Mikes as his "sorrowful predecessor".

Tollamat az éjszakába mártom, úgy írom ezt a levelet, apám. Egy új Rodostó álmait virrasztom idegen télben, idegen tanyán. És hallgatom a tenger mormolását, mint bús elödöm, Mikes Kelemen. De százszorta setétebbek az éjjek ezen az embertelen tengeren.

Szemem romok-szakgatta horizonton változó csillagok után kutat. De nem változnak még az égi képek s minden csillag Zágon felé mutat. És minden csillag egy-egy emlék bennem. ${ }^{6}$

[I plunge my pen into the night as I write this letter, father. 
I watch the dreams of a new Rodostó

in alien winter, at an alien camp.

And I listen to the murmuring of the sea,

like my sorrowful predecessor, Kelemen Mikes.

But the nights are hundred times darker

on this cruel sea.

My eyes chase changing stars

on the ruined horizon.

But the constellations do not move and every star point toward Zágon.

And each is a memory inside me.]

Wass was far from being a great poet, what is new in his text though, is that its very un-Mikes-like rage is directed towards someone who as a matter of fact had never been dealt with in the Mikes-reception: the one who moves into the home the émigré left behind, in Wass' view, an alien looking for prey, an alien whose nationality is easily identifiable, who encroaches upon the speaker's property, even if, as it is described later in the poem, both nature and culture, the trees and the house, resist him and try to keep him out, until a final historical judgment would take place to fix things again. With the figure of the alien that forces one to leave his home ground, Wass' poem represents an unusual, politically very sensitive refiguring of Mikes as a nationalist. It surely can be called an enormous misinterpretation of his Mikes' legacy; still it is illustrative of the 20th century history of political ideologies.

After World War II and the communist takeover, the various waves of exile were very diverse in terms of literary or political preference and regarding the respective age at which the émigrés decided or had the chance to leave. It was a common characteristic of these waves though that they managed to establish a well-developed network of organizations. One of the most prominent, and one of the few still operating, was the Kelemen Mikes Circle of the Netherlands, which was founded in 1951 by a handful of young protestant students and clergymen. (It is not to be confused with the other Kelemes Mikes Circle which was founded in Munich in 1959, round which mostly politically committed right-wing writers rallied, extreme right, I should say, and which disintegrated soon afterwards.) The young refugees and expatriates who founded the Mikes Circle of the Netherlands chose to both inhabit and renew the exilic tradition that Mikes emblematized. What they refused to do was to form a sort of Hungarian enclave, like the mock-court around Rákóczi in Rodostó. While keeping their cultural traditions, they also insisted on being part of the Dutch, that is, the Western world. They avoided the dilemma of complete assimilation on the one hand and nostalgic longing for the homeland on the other, and adopted, in a more pragmatic way, a double identity. The Mikes Circle, though remained local in its everyday workings, at- 
tracted a great number of emigrant Hungarian intellectuals, writers, and artists. Their annual assemblies were scholarly workshops of the highest standard.

Although coming from an older generation, the Mikes Circle had close connections with László Cs. Szabó, a prominent essayist, who left Hungary in 1948, settled in the United Kingdom, and was generally considered one of the spokesmen of the Hungarian exile. As a critical authority Cs. Szabó served as a father-figure to many of the youngsters in the Mikes Circle. He had his own vision of Mikes. In his 1966 essay, Under the Crescent Moon, Cs. Szabó rejects what he calls the "oleograph" inherited from the 19th century, which sentimentally portrays a gloomy Mikes mourning for himself by the seaside. ${ }^{7}$ Following his midwar domestic intellectual tradition, that of the Nyugat-circle, he also insists on Mikes's alleged ignorance to politics, which allegedly saved him from inner collapse. As such, Cs. Szabó might have aimed to distance himself from the emigrant political movements of his own age. However, even if his explicit aim was to detach Mikes' legacy from any political meaning whatsoever, Cs. Szabó's essay had its own political contexts. From the mid-1960s harsh disputes went on in the Hungarian exile whether to initiate any kind of dialogue with the officials of Hungary. Only one year after publishing his essay on Mikes, Cs. Szabó strictly opposed participation in the Mikes Circle's annual assembly where domestic intellectuals showed up, but not those they wanted to invite, but who gained the Party's permission to attend. Especially the appearance of the influential literary historian Miklós Szabolcsi met Cs. Szabó's disapproval. One might argue that when he objected to what he called a "mock-dialogue" based on uneven terms, he was chasing political illusions that he so wittily swept aside when writing on Mikes. ${ }^{8}$

One can hardly read Cs. Szabó's essay as not a self-portrait. His remarks about Mikes "standing head and shoulders above the domestic provinciality" of his age, ${ }^{9}$ clearly, I would suggest, refer to Cs. Szabó's conviction that exile provides a wider cultural horizon for him as well. Insisting that there is no need to have pity on Mikes, because he lived quite happily with his "inexhaustible mean of consolation", his pen, could be read as Cs. Szabó's disapproval of the way the exilic literature was treated in socialist Hungary as merely an expression of painful and nostalgic emotions. On the other hand, when Cs. Szabó suggests that the Letters form Turkey in its entirety should be translated into Western European languages, then this proposal refers to what became the ideological program of the Hungarian literary exile in the 1960-70s, that is, the mission of a two way cultural mediation between the motherland and the Western world.

One of the younger proponents of this program was Áron Kibédi Varga, both a scholar and a poet, and a Transylvanian by origin (just like Cs. Szabó and Wass and Jósika). Kibédi Varga fled Hungary in 1945 at the age of fifteen with his parents, and became a professor of French literature in Amsterdam. He was a co-founder of the Mikes Circle and a permanent contributor to their proceedings. 
One of his essays, entitled Mikes mitoszai [Myths of Mikes], originally a lecture, delivered in 1971 on the 20th anniversary of the Mikes Circle, starts with the following remark:

Mikes Kelemen nevét a magyar világtól távol élő magyarok a múltban is, ma is gyakran emlegetik. Mikes jelkép, jobb, pontosabb jelkép a hazájától elszakadt magyarságnak, mint akár Rákóczi vagy Kossuth; de félő, hogy ez a jelképszerüség többnyire még ma is a romantikus mítoszból táplálkozik. ${ }^{10}$

[Kelemen Mikes' name is and has been frequently mentioned by Hungarians living out of the Hungarian world. Mikes is a symbol, a better, more adequate symbol of the Hungarian detached from his homeland than Rákóczi or Kossuth; but it is to be feared that this symbolic force mostly subsists upon the romantic myth, even today.]

What is striking in this sentence is not that it promises to launch a severe attack on the romantic cult of Mikes. But that it states, without further ado, that Mikes is a symbol for and of the emigrants. As I have tried to argue, the main characteristic of Mikes' 19th century cult was that his exilic fate did not bring about any rupture in the way his image was employed in national self-representation. Kibédi Varga's remark clearly indicates a shift in that respect.

In addition, when Kibédi Varga rejects the lévaysms, the "murmuring of the sea" and the political illusions, he follows Cs. Szabó's path, but when he puts an emphasis on the fact that Mikes became a Hungarian writer abroad, then Kibédi Varga speaks from a different perspective, a perspective of his own generation and of the younger ' $56 \mathrm{ers}$, who came forth in the 1960s with their literary ambitions and eagerly tried to become writers abroad themselves. As opposed to Márai, Wass, Cs. Szabó, who all had successful literary careers before their emigration, Kibédi Varga seems to claim his generation to be the real successors of Mikes. This implicit claim is reinforced when he mentions in passing that Mikes writes in a pure and tasteful manner even having become a Hungarian writer abroad and having spent decades in exile. This note had its context in the debates whether exile necessarily leads to the decay of language or the loss of stylistic skills, which was feared by many among the older emigrant literati, a fear which in its most emblematic form was expressed in Márai's 1951 poem Funeral Sermon.

One can also notice a profound change of perspective in Kibédi Varga's view regarding the question what kind of writer had Mikes become in exile. Cs. Szabó praised Mikes as opposed to his Hungarian contemporaries. Kibédi Varga goes way beyond that and finds Mikes' real context in 20th century literary modernism. As he expounds, Letters from Turkey is not merely a novel, but a kind of self-reflexive literature that substitutes fiction for life in the manner of Proust and 
NAGY PAL

\section{ZÅGONI MIKES KELEMENNEK}

$$
\text { ba le fekszem ugy tettzik mint ba feredném }
$$

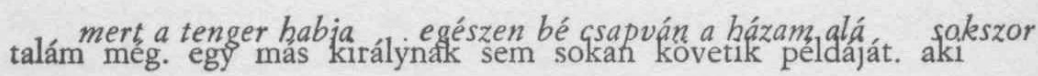

azt, gondoloin bogy az ágyamban locsog a viz [27] szeretven. az aszszonyokot, azon is igyekezet, hogy a tiz parancsola$a$ magzatvizben föltött idöre gondolok az anyaölben töltött
tot meg tarttsa, atobbi kozót egy aszszonyt szeretven. hogy mind

rövid idöre [ «mindässze buszonegy évet élt »...] a. az a parancsolatot meg tarthassa, mind a szeretetne kedvezhessen. vaországban
lamikor egy aszszonnyal akart teküssze, huszonegyet
$\square$ enevettséges példa, jeniköbe kacksiba lovakon egy buszonbét azt tarttyák. hogy a szeretetben.

éves ifjú érkezik "nyelyén a szó bimes szálgi \# dik, mindenkor alkalmatlan. látod-e néném, ha apasztor ot nem lett mikes a kas lisztes, a molnár egyepetye mókus
volna, a farkas meg ette volna abárányt, azt elmondhatni, hogy a szekergeti kerekét retet nem rosz. csak arra avégre igyekezék. amelyre az lsten rendelte, azért hóletlen határozók a búsába vág töbp mint negyven évig töhb mintt tizennégyezer napot több mint báromszázötvenezer órát
ki nem kel asni. minden jo édes nêném. mind az aszszony, a ferfiu. bor. ezüst, arany. tsakta füstölvén äreg a végre ellyujt [2] ezekel. a mélete végeig tettek., az $\square$ sten más a rubáját keresztet piseli a básbygi méltóságot

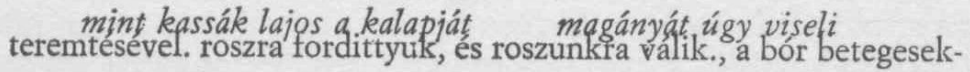
nek, aboryedïl kellé okgllgatom tenger mormolását » (ez tértsd szó szerint!) csak «q szó szakadó kusza szálai » $\square \square \square$ végül csak magokat. ihon édes nenem. vége vagyon már a predikácionak. fekügyünkle, és kívánok joéttzakát. és a mellé kevés bolhát, édes

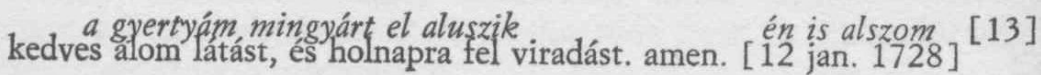
szaporodnak a tölgyfa levelei

zágoni mikes kelemennek nagy pál [12 jan. 1976] 
Borges. And to show that in this substitution fiction is victorious, Kibédi Varga quotes Letter 75, where Mikes insists that his own letters should be burned because they are way surpassed in literary quality by his aunts (non-existing) replies. For Kibédi Varga this modernist inversion of fact and fiction constitutes Mikes' real myth.

Precisely this literary modernity concerned the avant-garde poet Pál Nagy too, one of those young '56ers wanting to become a writer abroad. Nagy's poem dedicated to Mikes appeared in the Mikes Circle's 25th anniversary memorial volume in 1976. Nagy aims, with a peculiar visual gesture, to transcribe two historically distinct exilic literary traditions, Mikes' Baroque prose and his own avant-garde poetics in a palimpsest-like texture. ${ }^{11}$ The lines are in close proximity, one almost covering the other, as if two or more voices were speaking and resonating to one another. Among the fragmentary though recognizable quotations from Mikes' Letters, one can notice the name of the arch-avant-garde Hungarian poet, Lajos Kassák, an emigrant himself in Vienna during the 1920s. The line "mint kassák lajos a kalapját magányát úgy viseli" [like lajos kassák his hat he wears his solitude] refigures Mikes' obligatory loneliness with a somewhat surprising reference in literary history. Another, so to say, metafictional gesture is that when Nagy's poem quotes the most emblematic line of the most emblematic 19th century Mikes-poem, "egyedül hallgatom tenger mormolását", an ironic comment is added in brackets: "[ezt értsd szó szerint!]" (read this in the literal sense!). The call to read this worn out image in its literal meaning encourages the reader to get rid of the romantic clichés, to read Mikes' legacy against its inherited symbolic meanings. In a similar fashion, when calculating the years, the days, and the hours of Mikes' stay in Rodosto ("több mint negyven évig több mint tizennégyezer napot több mint háromszázötvenezer órát”, more than forty years, more than fourteen thousand days, more than three hundred and fifty thousand hours) the quantitative measuring downgrades the myth into trivial data. Nevertheless, by attempting to get rid of symbolism, Nagy ends up creating a new myth or symbol, that of the avant-garde Mikes.

Finally, I'd like to deal with three poems by Elemér Horváth, one of the best poets among the young '56ers. The first one appeared in 1984 in the domestic periodical Kortárs. In this case the place of publication is of specific importance, for up to the mid ' 80 s emigrant writers had been excluded from domestic periodicals. This one must have been one of the first poems Horváth was able to publish in Hungary. Therefore the title, Kegyelmi kérvény Mária Teréziához [A Plea for Clemency to Maria Theresa], sounds pretty much self-explanative and offers an easily decipherable allegory of the present political situation.

Az ifjú dolgát kérem Át-nem-gondolt

hatalmi érdek fogalmazta a 
legelső jelszavát pro patria

et libertate ahogy az utolsót

és ugyanazt úgy szeretem Rodostót

Életében először igaza

most van amikor be kell vallania

a tényeket ami csak történt sors volt

Folyamodván tehát idegen porból

őfelsége türelmes udvara

engedné-e hogy juthasson haza

a hátralévő esztendőkre? Gondot

azontúl lelkére fordítana

Bizalommal hogy lesz foganata Mikes Kelemen

[The case of this young man I beg your pardon Ill-advised power politics

formulated his first slogan pro patria

et libertate as well as the last one

and the same I like Rodostó so much

For the first time in his life he is right

now when he has to confess

the facts all that happened was destiny

Appealing from alien dust

if her majesty's patient court

allowed him to get home

for the years to come?

His only concern

would be his own soul

In the hope that it shall have its effects

Kelemen Mikes]

Like Nagy's poem, this one also gives the impression of being constructed out of quotations from Mikes. ${ }^{12}$ A role play, signed and authorized as if written by Mikes himself, the poem refers to Mikes' alleged application for amnesty, which is probably a myth itself. ${ }^{13}$ And as such, the text reflects the irony of Horváth's position of being published in Hungary, of having come home via his writings. It implies that what the plea aims at has already taken place by the very act of writing as pleading. However, the fact that the literary homecoming takes place as a plea for mercy suggests that homecoming cannot be complete; it can merely be a constant attempt.

Decades later, when exile was over and Horváth had already gained a literary reputation even in his homeland, he returns to the subject in two new poems. Both appeared in 2004 and seem to mutually interpret one another. The first, entitled lárpúrlár seems to be a sarcastic mocking: 


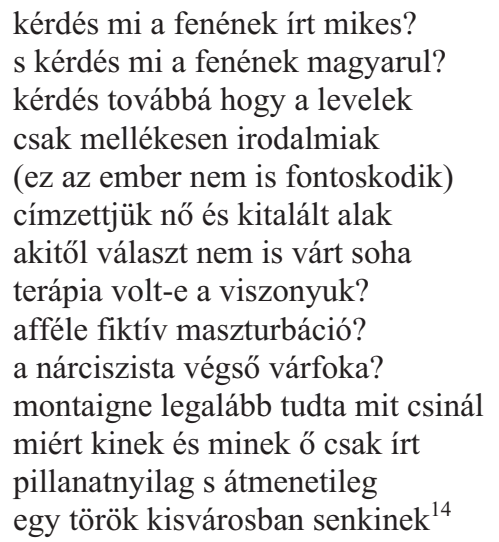

[question why on earth did mikes write?/ and why on earth in hungarian?/ also a question that the letters/ are only incidentally literary/ (this man doesn't even make a fuss)/ their addressee is female and fictional/ was their relation a therapy?/ some kinda fictitious masturbation?/ the ultimate rampart of narcissism?/ montaigne at least knew what he was doing/ why to whom and for what he just kept writing/ for the time being provisionally/ in a small turkish town to no one]

What is striking here is that some of these scorning questions reappear as gloomy statements in the other poem, called Házi feladat [Homework], retrospectively making irony out of its sarcasm:

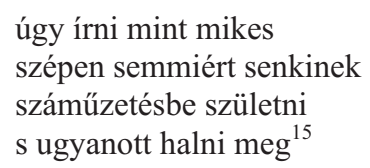

[to write like mikes/ nicely for nothing to no-one/ to be born in(to) exile/ and to die there too]

The educational sense of the phrase that gives the title, the notion of the task that students have to cope with when they get home, here is exaggerated as the task of one's whole life. In this extension, the poem profoundly redefines the concept of exile. Here one does not go into emigration; rather we are born into it. The notion of being born into exile can be traced back to a lecture that Győző Határ, the recently deceased excellent novelist, delivered at the 1976 assembly of the Mikes Circle, which started with the harshly provocative statements: "I was born in 13 November 1914 - in exile. [...] At the end of 1956 I left Hungary and came home. I've been living at home ever since. At home in England [...]". ${ }^{16}$ The hint that the homeland is a place of exile also appears in Márai's text, attributing this genuine homelessness particularly to Hungarian writers, but while Határ reverses the di- 
chotomy of being-at-home and being-in-exile, Márai does not suggest that he would feel at home living abroad either. As opposed to both, Horváth's poem dissolves the whole structure of oppositions, suggesting that it is probably not a question of being a writer at all. That exile is there not only when one becomes a writer, but at the very moment he or she is born. If Horváth's poem suggests that the human condition can never transcend the state of being foreign, then it marks a significant stage in Mikes's cult: it moves beyond the transition from the notion of literature of exile to that of literature as exile, and opens up the horizon on life as an inherently exilic experience.

\section{Notes}

1 Miklós Jósika to Miklós Fejérváry, Brussels 1 June 1862, in Károly Kokas and Mihály Szajbély (eds) (1988) “Idegen de szabad hazában” (Budapest: Szépirodalmi). 357.

2 Miklós Jósika (1861) Második Rákóczi Ferenc. 6 vols. (Pest: Hartleben).

3 For a detailed analysis of Mikes's similar dilemmas, see Sándor Bene (2007) 'Eljutni Zágonba', Holmi, 551-70.

4 Ferenc Toldy (ed.) (1861) Zágoni Mikes Kelemen törökországi levelei (Pest: Heckenast).

5 Sándor Márai [1942] 'Csillag' in Sándor Márai (1994) Vasárnapi krónika (Budapest: Gondolat) 224.

6 Albert Wass [1948] 'Levél' in Albert Wass (1998) A bujdosó imája: Összegyüjtött versek (Budapest: Püski) 94-8. (Italics are mine.)

7 László Cs. Szabó ‘A félhold jegyében: Zrínyi Miklós, a költő és Mikes Kelemen' [1967] in László Cs. Szabó (1982) Alkalom. Esszék irodalomról, müvészetről (Budapest: Gondolat). 242-80.

8 Quoted in Enikő Gaál (2001) 'A Hollandiai Mikes Kelemen Kör mint a nyugat-európai magyar emigráció kulturális fellegvára' in Melinda Kónya, Áron Kibédi Varga and Zoltán Piri (eds) Számadás. Hollandiai Mikes Kelemen Kör (1951-2001) (Pozsony: Kalligram), 228 (186-236).

9 Cs. Szabó, Alkalom, 280.

10 Áron Kibédi Varga 'Mikes mítoszai' (1976) in M. Tóth (ed.) Az embernek próbája: Emlékkönyv ... a Hollandiai Mikes Kelemen Kör fennállásának huszonötödik évfordulójára (Amszterdam: Hollandiai Mikes Kelemen Kör), 31 (31-35).

11 Pál Nagy (1976) 'Zágoni Mikes Kelemennek (1976. jan. 12.)' in Miklós Tóth (ed.) $A z$ embernek próbája, op. cit., 30.

12 Elemér Horváth (1984) 'Kegyelmi kérvény Mária Teréziához’ Kortárs, Vol. 7, 1061.

13 See Sándor Bene 'Eljutni Zágonba', 555.

14 Elemér Horváth (2004) 'lárpúrlár', Forrás, Vol. 10, 15.

15 Elemér Horváth (2004) 'Házi feladat', Holmi, 925.

16 '1914. november 13-án, emigrációban születtem. Azóta itthon élek - Itthon Angliában.' Győző Határ 'Istenhozzád, emigráció!' [1976] in Béla Pomogáts (ed.) (1991) Párbeszéd Magyarországgal. Nyugat-európai és tengerentúli magyar tanulmányírók (Budapest: Szépirodalmi), 370 (370-87). 